\title{
Alpha-tocopherol concentration in serum and colostrum of mothers with gestational diabetes mellitus
}

\author{
Concentração de $\alpha$-tocoferol no soro e colostro de mães com diabetes melito gestacional \\ Concentración de $\alpha$-tocoferol en el suero y calostro de madres con diabetes mellitus gestacional
}

Fernanda Barros S. Resende1, Heleni Aires Clemente1, Dalila Fernandes Bezerra1', Evellyn Câmara Grilo', Larisse Rayanne M. de Melo1, Paula Emília N. R. Bellot ${ }^{1}$, Raquel Costa S. Dantas ${ }^{1}$, Roberto Dimenstein ${ }^{1}$

\section{ABSTRACT}

Objective: To evaluate and compare the levels of $\alpha$-tocopherol in colostrum and in the serum of healthy and diabetic mothers.

Methods: This cross-sectional study enrolled 51 volunteer mothers, 20 with the diagnosis of gestational diabetes mellitus and 31 without associated diseases. Serum and colostrum samples were collected in fasting in the immediate postpartum period and $\alpha$-tocopherol was analyzed by high performance liquid chromatography (HPLC). In order to define the nutritional status of vitamin $\mathrm{E}$, the cutoff point for the serum $(697.7 \mu \mathrm{g} / \mathrm{dL})$ was adopted. Student's t-test for independent variables compared the average concentrations of $\alpha$-tocopherol in the serum and in the colostrum between control and gestational diabetes mellitus groups. Pearson's correlation was used to assess the relationship between the concentration of $\alpha$-tocopherol in serum and colostrum for both groups. Differences were considered significant when $p<0.05$.

Results: The $\alpha$-tocopherol concentration in colostrum was $1,483.1 \pm 533.8 \mu \mathrm{g} / \mathrm{dL}$ for Control Group and $1,368.8 \pm 681.8 \mu \mathrm{g} / \mathrm{dL}$ for diabetic women, without differences between groups $(p=0.50)$. However, $\alpha$-tocopherol concentration in the serum was $1,059.5 \pm 372.7 \mu \mathrm{g} / \mathrm{dL}$ in the

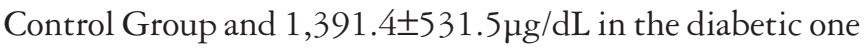
$(p<0.01)$. No correlation was found between the concentra- tion of $\alpha$-tocopherol in the serum and in the colostrum for control and diabetic groups.

Conclusions: The groups had adequate nutritional status of vitamin E. Gestational diabetes was not associated with changes in $\alpha$-tocopherol concentration in colostrum.

Key-words: diabetes, gestational; colostrum; serum; alpha-tocopherol.

\section{RESUMO}

Objetivo: Avaliar e comparar a concentração de $\alpha$-tocoferol no leite colostro e no soro de mães diabéticas e saudáveis.

Métodos: Estudo transversal, realizado com 51 parturientes voluntárias, sendo 20 diagnosticadas com diabetes melito gestacional e 31 sem nenhuma doença associada. Coletaram-se as amostras de soro e de colostro em jejum no pós-parto imediato e o $\alpha$-tocoferol foi analisado por cromatografia líquida de alta eficiência (CLAE). Para definir o estado nutricional de vitamina $\mathrm{E}$, adotou-se ponto de corte sérico $(697,7 \mu \mathrm{g} / \mathrm{dL})$. O teste $t$ de Student para variáveis independentes comparou as concentrações médias de $\alpha$-tocoferol no soro e no colostro entre os grupos controle e com diabetes melito gestacional. A correlação de Pearson testou a relação entre a concentração de $\alpha$-tocoferol no soro e no colostro para ambos os grupos. As diferenças foram consideradas significantes quando $p<0,05$.
Instituição: Universidade Federal do Rio Grande do Norte (UFRN), Natal, RN, Brasil

'UFRN, Natal, RN, Brasil
Endereço para correspondência:

Roberto Dimenstein

Avenida Senador Salgado Filho, 3.000 - Lagoa Nova

CEP 59072-970 - Natal/RN

E-mail: rdimenstein@gmail.com

Conflito de interesse: nada a declarar

Recebido em: 9/9/2013

Aprovado em: 28/11/2013 
Resultados: As concentrações de $\alpha$-tocoferol no colostro foram $1.483,1 \pm 533,8 \mu \mathrm{g} / \mathrm{dL}$ para as mulheres do Grupo Controle e $1.368,8 \pm 681,8 \mu \mathrm{g} / \mathrm{dL}$ para as diabéticas, não havendo diferenças $(p=0,50)$. Entretanto, no soro das puérperas controle, a concentração de $\alpha$-tocoferol foi $1.059,5 \pm 372,7 \mu \mathrm{g} / \mathrm{dL}$ e, nas diabéticas, $1.391,4 \pm 531,5 \mu \mathrm{g} / \mathrm{dL}, \operatorname{com} p<0,01$. Não houve correlação entre a concentração de $\alpha$-tocoferol no soro e no colostro para o Grupo Controle. Resultado semelhante foi encontrado para o grupo com diabetes melito gestacional.

Conclusões: Os grupos apresentaram estado nutricional adequado quanto à vitamina $\mathrm{E}$. Não houve associação entre diabetes melito gestacional e mudanças na concentração de $\alpha$-tocoferol no colostro.

Palavras-chave: diabetes gestacional; colostro; soro; alfa-tocoferol.

\section{RESUMEN}

Objetivo: Evaluar y comparar la concentración de $\alpha$-tocoferol en la leche calostro y en el suero de madres diabéticas y sanas.

Métodos: Estudio transversal, realizado con 51 parturientes voluntarias, siendo 20 diagnosticadas con diabetes mellitus gestacional y 31 sin cualquier enfermedad asociada. Se recogieron las muestras de suero y de calostro en ayuno en el postparto inmediato y se analizó el $\alpha$-tocoferol por cromatografía líquida de alta eficiencia (CLAE). Para definir el estado nutricional de vitamina E, se adoptó el punto de corte sérico $(697,7 \mu \mathrm{g} / \mathrm{dL})$. El análisis estadístico se realizó con la prueba $t$ de Student para variables independientes a fin de comparar las concentraciones medianas de $\alpha$-tocoferol en el suero entre los grupos control y con diabetes mellitus gestacional. Ese análisis también fue realizado para comparar los promedios de $\alpha$-tocoferol en el calostro en los grupos estudiados. Se utilizó la correlación de Pearson para evaluar la relación entre la concentración de $\alpha$-tocoferol en el suero y en el calostro para ambos grupos. Las diferencias fueron consideradas significativas cuando $p<0,05$.

Resultados: Las concentraciones de $\alpha$-tocoferol en el calostro fueron $1.483,1 \pm 533,8 \mu \mathrm{g} / \mathrm{dL}$ para las mujeres del Grupo Control y $1.368,8 \pm 681,8 \mu \mathrm{g} / \mathrm{dL}$ para las diabéticas, no habiendo diferencias $(p=0,50)$. Sin embargo, en el suero de las puérperas control, la concentración de $\alpha$-tocoferol fue $1.059,5 \pm 72,7 \mu \mathrm{g} / \mathrm{dL}$ y, en las diabéticas, $1.391,4 \pm 531,5 \mu \mathrm{g} /$ $\mathrm{dL}, \operatorname{con} p<0,01)$. No hubo correlación entre la concentración de $\alpha$-tocoferol en el suero y en el calostro para el Grupo
Control. Resultado semejante fue encontrado para el grupo con diabetes mellitus gestacional.

Conclusiones: Los grupos presentaron estado nutricional adecuado respecto a la vitamina $\mathrm{E}$. No hubo asociación entre diabetes mellitus gestacional y concentración de $\alpha$-tocoferol en el calostro.

Palabras clave: diabetes gestacional; calostro; suero; $\alpha$-tocoferol.

\section{Introduction}

During pregnancy, there is usually an accumulation of energy reserves, characterized by common maternal physiological responses to pregnancy, such as increased visceral fat, insulin resistance, and increased circulating lipids ${ }^{(1)}$. Insulin resistance promotes the increase in glucose concentration, characterizing a scenario of gestational diabetes mellitus (GDM). Studies have shown the occurrence of increased production of oxygen free radicals, supporting the hypothesis that there is increased oxidative stress in patients with gestational diabetes ${ }^{(2)}$. However, there are still some knowledge gaps regarding oxidative stress during pregnancy and their reflection on neonates.

GDM carries several mother-baby risk factors, among them, the increased incidence of teratogenicity, higher in fetuses of diabetic mothers when compared to healthy mothers, being this malformations also resulting from the cellular damage caused by the activity of free radicals ${ }^{(2)}$.

The natural antioxidants reduce the adverse effects of free radicals because they have the ability to capture and neutralize reactive oxygen species (ROE), preventing lipid peroxidation. This neutralization is essential, especially in situations of increased oxidative stress, as in $\mathrm{GDM}^{(3)}$. Among these substances, vitamin E stands out, essential micronutrient that corresponds to a group of eight fat soluble compounds classified as $\alpha-, \beta-, \gamma$-, and $\delta$-tocopherol or tocotrienol, being $\alpha$-tocopherol the most active biologically ${ }^{(4)}$.

It is known that the placental transfer of vitamin $\mathrm{E}$ during pregnancy is limited and reservations of this micronutrient formed in the newborn are low, making exclusive breastfeeding the only source of acquisition to meet their nutritional needs ${ }^{(4)}$. This offer is extremely important, since the exposure to hyperoxia at birth increases the risk of formation of free radicals ${ }^{(5)}$. Researchers evaluated the relationship between diabetes and vitamin $\mathrm{E}$ and found that its supplementation is related to the production of insulin and the protection of pancreatic beta cells, revealing that vitamin $\mathrm{E}$ might be directly related to diabetes ${ }^{(6)}$. 
Given the importance of vitamin E to the mother-child binomial, this study aimed to verify the alpha-tocopherol concentration in serum and colostrum of mothers with gestational diabetes mellitus and in healthy mothers, as well as to compare the vitamin values between groups. The relevance of this work consist on verifying whether GDM can be a risk factor for vitamin E deficiency in parturient women and/or newborns, considering that breast milk is the only source of this vitamin to newborns in exclusive breastfeeding.

\section{Method}

The present study has a cross-sectional design, and was conducted with 51 volunteer mothers, 20 diabetic and 31 without associated diseases, all treated in a public maternity service in the municipality of Natal, state of Rio Grande do Norte. The samples were collected from October 2011 to August 2012.

For the sample size calculation, we used the G*Power software, version $3 \cdot 1 \cdot 7^{(7)}$. The calculation was performed considering the following parameters: $\alpha=5 \%, 80 \%$ test power, and expectation of the effect measure of 0.81 . The total size indicated for the sample was of 50 cases.

Exclusion criteria for the group of healthy parturient women were: presence of diseases (diabetes, hypertension, neoplasia, gastrointestinal tract, and liver diseases, heart diseases, infectious syphilis, and HIV positive); use of vitamin supplements containing vitamin E during pregnancy; multiple fetuses or with malformations. Regarding mothers with gestational diabetes, the insulin-depended, those with multiple fetuses or fetuses with malformations, and those who used vitamin supplements during pregnancy were excluded. The diagnosis of GDM was made by the medical staff during the prenatal of the participants. For positive screening during prenatal care regardless of the gestational period, it was established that maternal fasting blood glucose should be $\geq 85 \mathrm{mg} / \mathrm{dL}$. For the diagnosis of GDM, we used the cutoffs of $110 \mathrm{mg} / \mathrm{dL}$ for fasting glucose and of $140 \mathrm{mg} / \mathrm{dL}$ for the value of the Oral Glucose Tolerance Test (OGTT), performed 2 hours after oral administration of $75 \mathrm{~g}$ glucose.

All procedures of the study were approved by the Research Ethics Committee of the University Hospital Onofre Lopes within Universidade Federal do Rio Grande do Norte (UFRN), under protocol n. 325/09. All participants were informed about the study and signed the informed consent.

Data on maternal and obstetric characteristics were obtained from medical records of the women in labor, the pre-natal care card, and through interviews conducted by the researchers. The pre-pregnancy anthropometric nutritional status was determined by the body mass index (BMI), calculated as the ratio between the normal body weight of the woman before pregnancy and her height squared. Women with BMI $<19.8 \mathrm{~kg} / \mathrm{m}^{2}$ were classified as underweight; those with a BMI between $19.8-26 \mathrm{~kg} / \mathrm{m}^{2}$ as eutrophic; women with BMI between $26-29 \mathrm{~kg} / \mathrm{m}^{2}$ were classified as overweight, and women with $\mathrm{BMI}>29 \mathrm{~kg} / \mathrm{m}^{2}$ were classified as obese ${ }^{(8)}$.

The gestational weight gain of participants was calculated as the difference between the pre-partum body weight and the pre-pregnancy weight and assessed in accordance with the recommendations by the Institute of Medicine ${ }^{(8)}$. Women with low pre-pregnancy weight should gain between $12.5-18 \mathrm{~kg}$ until the end of pregnancy; those with adequate pre-gestational weight, between $11.5-16 \mathrm{~kg}$; those with overweight, between 7-11.5kg; and obese women should gain about $7 \mathrm{~kg}$ until the end of pregnancy.

Data on the characteristics of newborns of participating mothers were obtained from medical records. Newborns were classified according to gestational age in preterm (those born with less than 37 weeks) and term infants (those born between the 37 th and the 42 th week ${ }^{(9)}$. The newborns were also classified according to birth weight in underweight $(2,500 \mathrm{~g})$; adequate weight (weight between 2,500 and $4,000 \mathrm{~g}$ ); and macrosomic (weight above $4,000 \mathrm{~g}$ ) ${ }^{(10)}$.

On the first day postpartum, $2 \mathrm{~mL}$ of colostrum and $5 \mathrm{~mL}$ of blood were collected from each parturient involved in the study. These biological samples were collected in the morning after fasting for about 8 to 12 hours. Colostrum was obtained by manual expression from a single breast to prevent fluctuation in fat, and blood was obtained by venipuncture. The samples were collected in polypropylene tubes, protected from light and transported in coolers to the Laboratory of Food and Nutrition Biochemistry at the Biochemistry Department of UFRN. The colostrum samples were subjected to water-bath at $37^{\circ} \mathrm{C}$ for 5 minutes and stirred for homogenization of the sample. Then, an aliquot of $500 \mu \mathrm{L}$ was placed in a light-protected polypropylene tube and stored at $-18^{\circ} \mathrm{C}$ until analysis. Blood was centrifuged to remove the serum, and $1 \mathrm{~mL}$ was separated ad stored with the same procedure performed with the colostrum.

The alpha-tocopherol concentrations in the samples of serum and colostrum were determined by high performance liquid chromatography (HPLC). Biochemical analysis of $\alpha$-tocopherol in biological samples occurred according to the adaptation of the extraction method used by Ortega $e t a^{(11)}$, as described below. For $1 \mathrm{~mL}$ of serum, $1 \mathrm{~mL}$ of ethanol $95 \%$ (Merck ${ }^{\circledR}$, USA) was 
used; and then, there were two extractions with $2 \mathrm{~mL}$ of hexane (Merck $^{\circledR}, \mathrm{USA}$ ), and evaporation of $2 \mathrm{~mL}$ of hexane extract in a water bath at $37^{\circ} \mathrm{C}$. For $500 \mu \mathrm{L}$ of colostrum, $500 \mu \mathrm{L}$ of ethanol 95\% (Merck ${ }^{\circledR}$, USA) were added; then, two extractions with $2 \mathrm{~mL}$ of hexane (Merck ${ }^{\circledR}, \mathrm{USA}$ ), and evaporation in the same conditions as the serum. After these proceedings, the samples were redissolved in $500 \mu \mathrm{L}$ of absolute ethanol $\left(\mathrm{Vetec}^{\circledR}, \mathrm{Brazil}\right)$ and $20 \mu \mathrm{L}$ were applied to the HPLC apparatus (model LC-10 AD, Shimadzu Corporation ${ }^{\circledR}$, Japan) coupled to a UV-VIS detector (SPD-10 A, Shimadzu Corporation ${ }^{\circledR}$, Japan) and to a Chromatopac C-R6A integrator (Shimadzu Corporation ${ }^{\circledR}$, Japan). A reverse phase column was used (CLC-ODS (M), Shim-pack, Japan) $4.6 \mathrm{~mm}$ d.i.x $25 \mathrm{~cm}$ in length. The mobile phase used in these analyses was of methanol $100 \%$ (J. T. Baker, Mexico) at a flow rate of $1.0 \mathrm{~mL} /$ minute.

The $\alpha$-tocopherol was identified in the samples by comparing the retention time of the peaks obtained in the chromatograms and that obtained by applying the standard $\alpha$-tocopherol Sigma ${ }^{\circledR}$. In order to quantify $\alpha$-tocopherol in biological samples, we used a standard curve for external standardization. The concentration of the standard was confirmed by specific extinction coefficient in absolute etha$\mathrm{nol}^{(12)}, \varepsilon 1 \%, 1 \mathrm{~cm}=75.8$ to $292 \mathrm{~nm}\left(\right.$ Sigma $^{\circledR}$, USA).

Concentrations of maternal $\alpha$-tocopherol serum levels above $697.7 \mu \mathrm{g} / \mathrm{dL}$ are considered acceptable, according to the values established by Sauberlich ${ }^{(13)}$.

To determine the precision and accuracy, there were tests of recovery and repeatability expressed by relative standard deviation (RSD), with three concentrations, (50, 100, and $200 \mathrm{ng} / \mathrm{mL}$ ), contemplating the range of variation within the linearity curve. We also determined the detection limit (DL) and the quantitation limit (QL).

The $\alpha$-tocopherol was found in colostrum and serum. The average rate of recovery of $\alpha$-tocopherol in the serum was of $100 \%$ and, for colostrum, of $98.8 \%$. The measurements were characterized by satisfactory repeatability, with RSD of serum and colostrum from 7.7 and $4.2 \%$, respectively.

To determine the DL and the QL, we diluted the samples of serum and colostrum, whose concentrations were known. For each dilution, the samples were applied and the peak was observed, so that the DL was determined when there was no more distinction between the noise and the analytical signal, which was reached in the concentration of $3.18 \mathrm{ng} / \mathrm{mL}$. The QL was determined when the analytical signal was detected in the lower dilution, equivalent to $6.36 \mathrm{ng} / \mathrm{mL}$, according to the visual method ${ }^{(14)}$. The calibration curve was performed with standard solutions of $\alpha$-tocopherol (Sigma ${ }^{\circledR}$ ).
The calibration curve for $\alpha$-tocopherol was linear $\left(\mathrm{r}^{2}=0.9998\right)$ and obtained within $1.2-41.3 \mu \mathrm{g} / \mathrm{mL}$.

We analyzed the data by Statistic Release $7^{\circledR}$, and they are presented as mean and standard deviation. We used the Kolmogorov-Smirnov test to check the normality of the metric variables of interest. After verification of normality, we used the Student $t$ test for independent variables, in order to determine whether there is significant difference between the means of $\alpha$-tocopherol in the studied groups. We used the Pearson correlation to assess the relationship between the concentration of $\alpha$-tocopherol in serum and colostrum, establishing significance at $p<0.05$. This correlation was performed for each studied group.

Table 1 - Characteristics of the study population based on maternal, obstetric, and neonate's characteristics

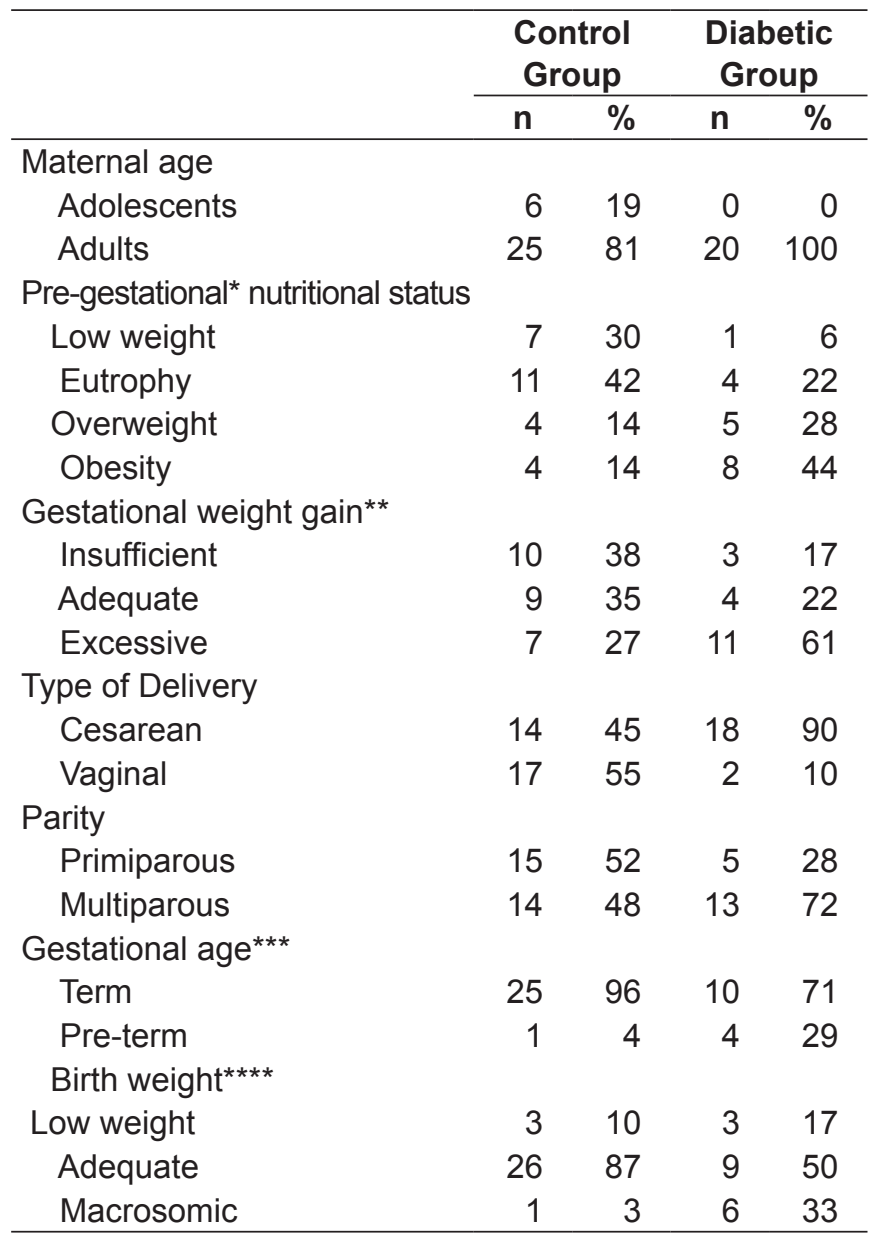

*Pre-pregnancy nutritional status classified according to the level of pre-gestational body mass index ${ }^{(8)}$; ${ }^{* *}$ gestational weight classified according to pre-gestational nutritional status ${ }^{(8) ;}$; ${ }^{* *}$ pre-term: gestational age $<37$ weeks and term: $37 \leq$ gestational age $<42$ weeks $^{(9)} ;{ }^{* \star * *}$ low weight: birth weight $<2,500 \mathrm{~g}$, adequate weight: $2,500 \mathrm{~g} \leq$ birth weight $\leq 4,000 \mathrm{~g}$ e macrosomy: birth weight $>4,000 \mathrm{~g}^{(10)}$ 


\section{Results}

Parturients who participated in this study were distributed for the analysis of results in two groups: Control $(n=31)$ and gestational diabetes mellitus group $(n=20)$.

Women included in the control group were mostly adult $(81 \%)$, were submitted to vaginal delivery (55\%), and had term $(96 \%)$ and normal weight children $(87 \%)$. As to prepregnancy weight, $42 \%$ were classified as eutrophic. The mean gestational age (GA) of newborns of parturient women in this group was of $39 \pm 1.2$ weeks, and only one newborn was classified as pre-term, with a GA of 36 weeks. As for pregnant women included in the diabetic group, all were adults and most had cesareans, (90\%) and term children (71\%). Regarding the classification of pre-pregnancy weight, $44 \%$ were obese. As for the weight of newborns in this group, $33.3 \%$ were born underweight, $33.3 \%$ had adequate weight, and $33.3 \%$ were macrosomic. The mean GA of infants from mothers included in this group was of $37 \pm 2$ weeks and four infants were classified as preterm, being the mean gestational age of $35 \pm 1$ weeks (Table 1 ).

In pregnant women in the control group, the mean $\alpha$-tocopherol concentration found in serum was of $1,059.5 \pm 372.7 \mu \mathrm{g} / \mathrm{dL}$ (minimum: 482.3; maximum:

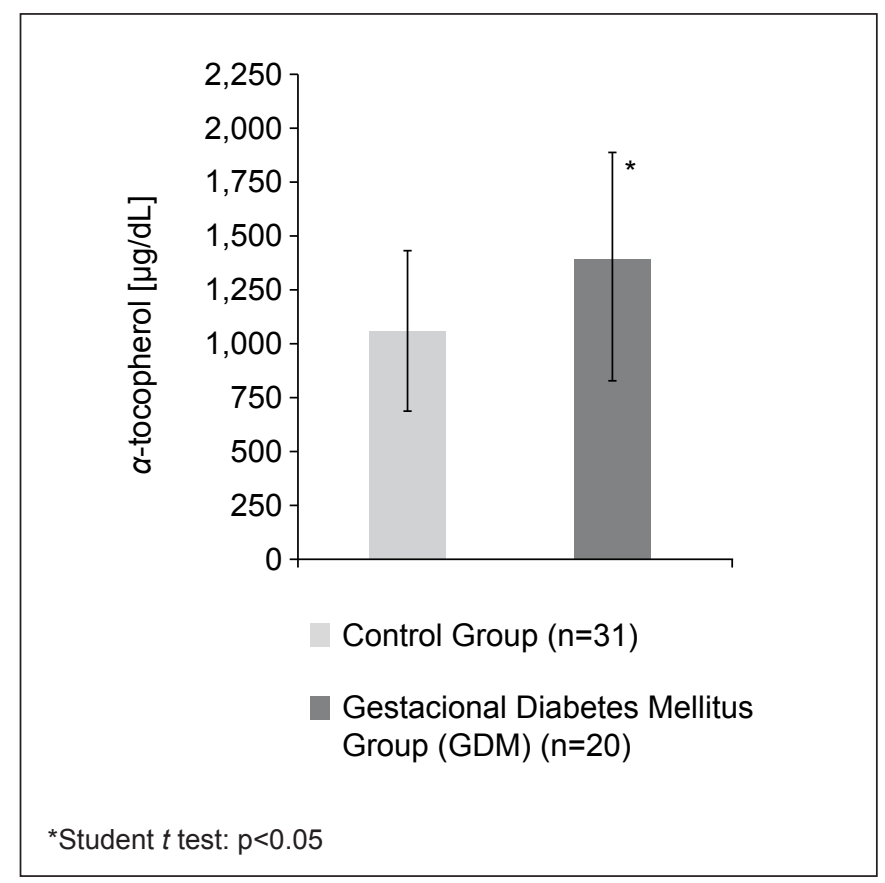

Figure 1 - $\alpha$-tocopherol concentration in serum of lactating women in the Control Group and in the Gestational Diabetes Mellitus Group
$2,405.8)$. For the group of diabetic women, the mean was of $1,391.4 \pm 531.5 \mu \mathrm{g} / \mathrm{dL}$ (minimum: 368.0; maximum: 2,311.5), with a significant difference between the groups $(p<0.01)$ (Figure 1$)$. The $\alpha$-tocopherol concentration in colostrum was of $1,483.1 \pm 533.8 \mu \mathrm{g} / \mathrm{dL}$ (minimum: 645.5; maximum: 2,360.1) for participants in Control Group and of $1,368.8 \pm 681.8 \mu \mathrm{g} / \mathrm{dL}$ (minimum: 505.6; maximum: 2,750.6) for diabetic women, with no difference between groups (Figure 2). No correlation was found between serum and colostrum for both the control group $(p>0.05 ; \mathrm{r}=0.12)$ and the GDM group $(p>0.05 ; \mathrm{r}=-0.11)$. The correlation for both groups is expressed in Figures 3 and 4.

\section{Discussion}

The maternal nutritional state pre- and during pregnancy is one of the most important variable factors for the motherchild health. The inadequacy of the maternal nutritional state influences the outcome of pregnancy and the conditions of growth presented by the newborn, as the gestational period is a phase in which the nutritional needs are high, due to physiological adjustments of the pregnant woman and the nutritional demands for fetal growth ${ }^{(15)}$.

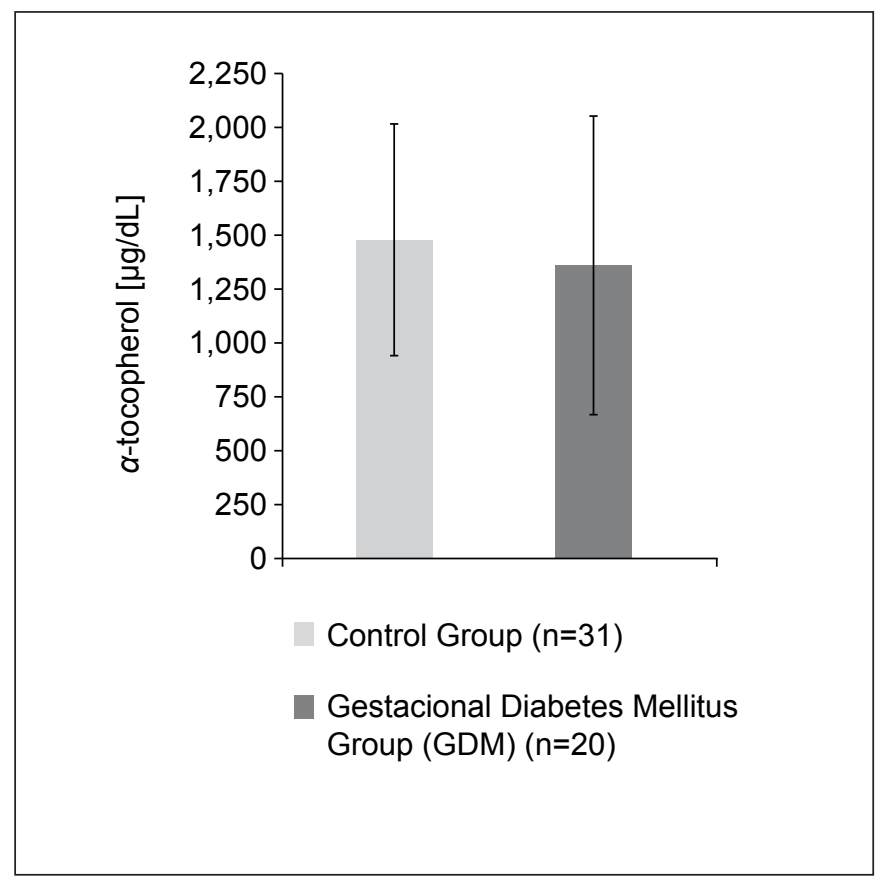

Figure 2 - Concentration of $\alpha$-tocopherol in colostrum of lactating women in the Control Group and in the Group with Gestational Diabetes Mellitus 


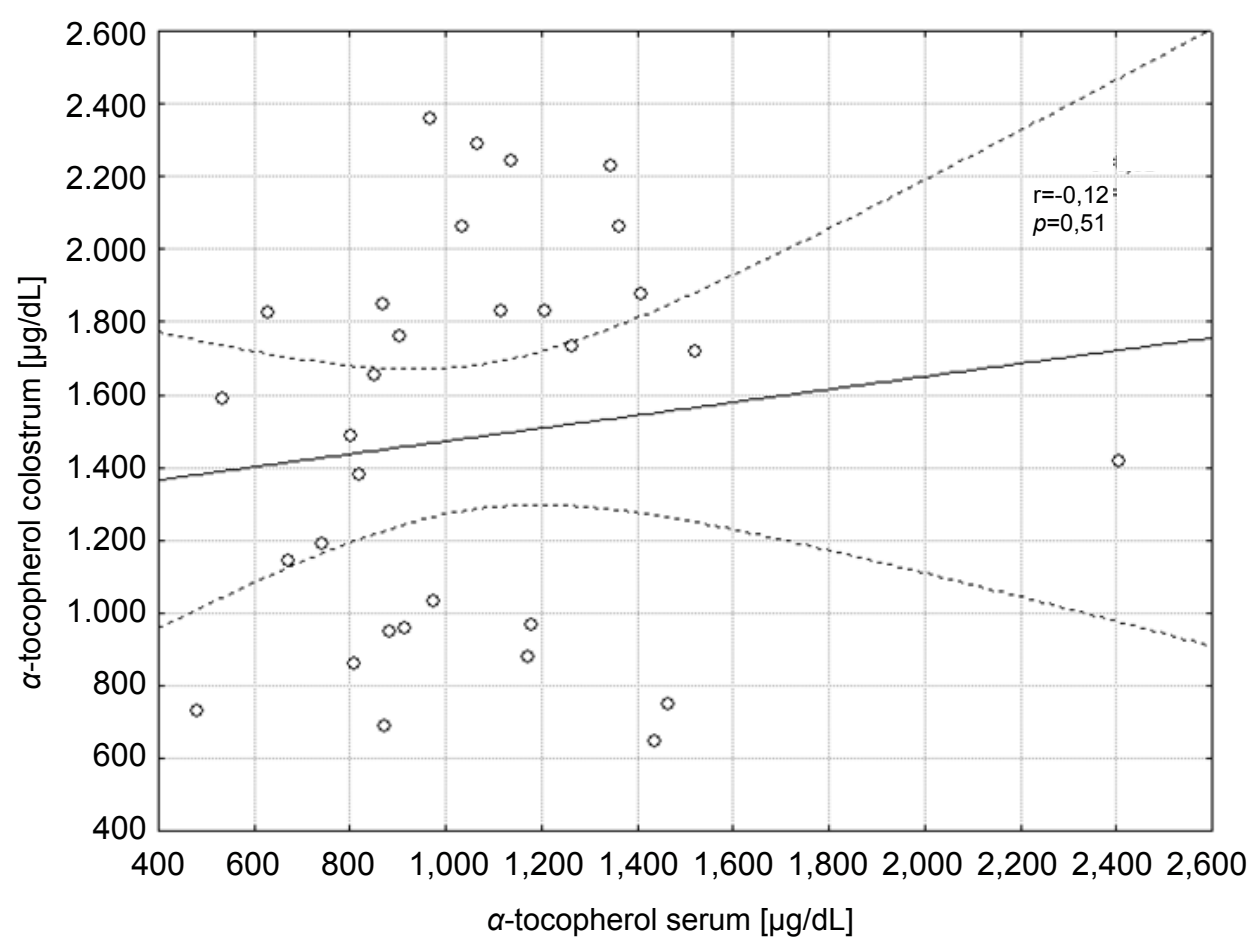

— Linear regression straight line; --- 95\% Confidence Interval for the linear regression

Figure 3 - Correlation between $\alpha$-tocopherol concentration in the serum and colostrum of lactating women in Control Group

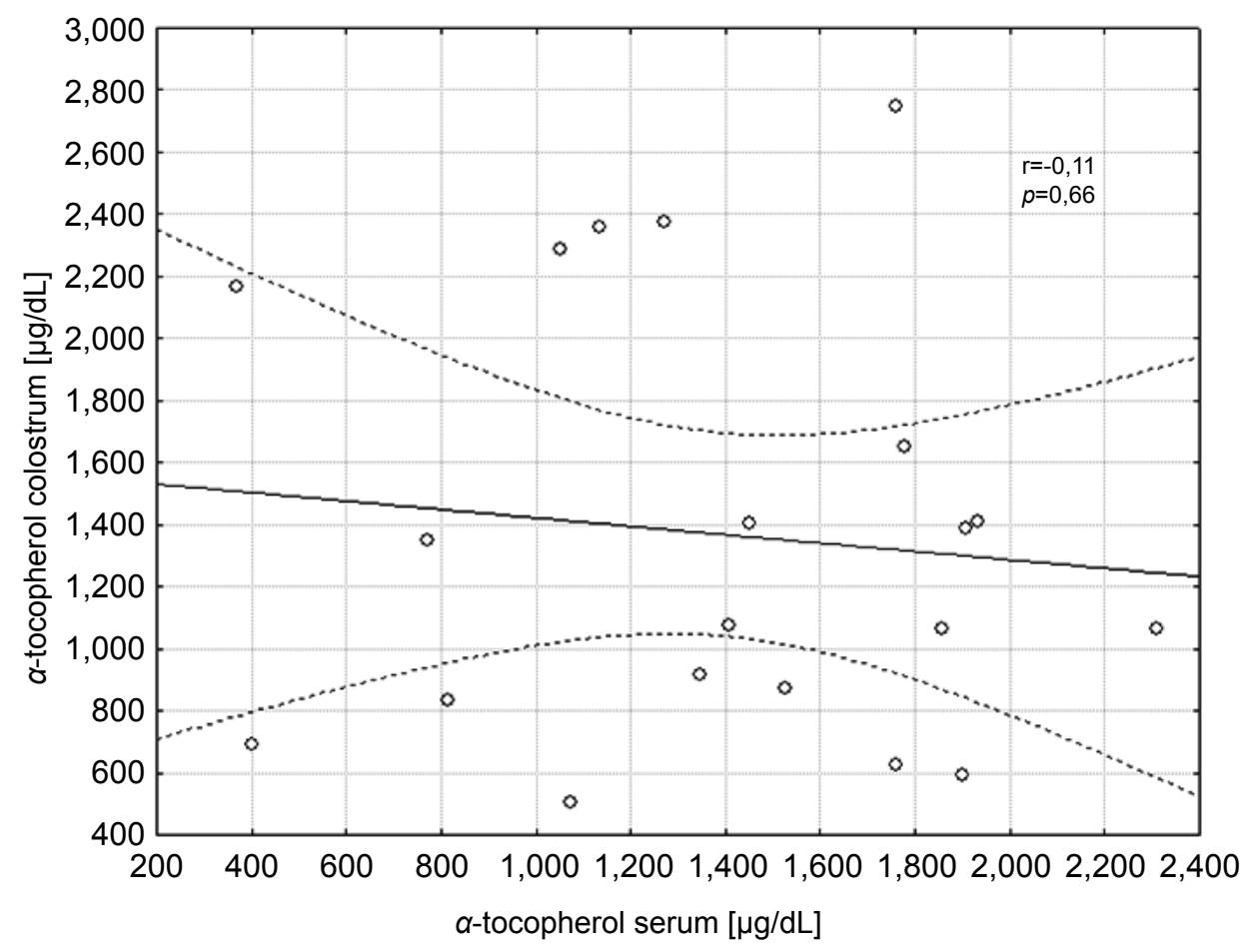

- Straight linear regression; --- Confidence interval of $95 \%$ of the linear regression

Figure 4 - Correlation between the concentration of $\alpha$-tocopherol in serum and colostrum of lactating women from the Group of Gestational Diabetes Mellitus 
From the means of $\alpha$-tocopherol serum concentrations observed in both groups, the nutritional biochemical state of the serum is acceptable ${ }^{(13)}$, and there was no deficiency related to diabetes. Regarding the colostrum, it was verified that both groups meet the nutritional requirement of the newborn, considering that the estimated volume of colostrum ingestion is of $500 \mathrm{~mL} / \mathrm{day}^{(16)}$, and the result was compared directly to the 2000 reference value of the Institute of Medicine ${ }^{(17)}$ for the ingestion of the nutrient $(4 \mathrm{mg} /$ day).

From the results, it was observed that the serum of women with GDM showed higher $\alpha$-tocopherol concentrations when compared to healthy mothers. However, Grissa et al ${ }^{(18)}$ and Peuchant $e t a l^{(19)}$, in a study conducted with pregnant women, reported a decrease in vitamin $\mathrm{E}$ concentrations when compared to those of healthy mothers. Suhail et al ${ }^{(20)}$ also found decreased serum concentrations compared to the control group. However, these authors carried out the collection at delivery, unlike this study, in which samples were collected from samples in the first day postpartum.

In studies conducted by Lammi-Keefe $e t a^{(21)}$ and Dey et a ${ }^{(22)}$, there was no significant difference between the amount of tocopherol in the serum of the diabetic group and the healthy group. The study by Lammi-Keefe et $a^{(21)}$ was the first conducted with insulin-dependent diabetes mellitus lactating women and their respective control group, composed of healthy lactating women. The second study was conducted in India and analyzed tocopherol in pregnant women diagnosed with gestational diabetes. However, another study conducted in India by Santra et al ${ }^{(23)}$ found a higher amount of vitamin $\mathrm{E}$ in the serum of women with GDM compared to the control group, confirming the results obtained in this research. The amount of vitamin $\mathrm{E}$ has undergone gradual increase even after 4 weeks, though new serum collection.

Increased $\alpha$-tocopherol serum concentration may be related to metabolic changes that occur in the maternal body due to GDM. At the end of pregnancy, there should be a reduction in insulin secretion, leading to a hormonal response that make tissues dependent on insulin to metabolize lipids instead of carbohydrates, initiating a process of lipolysis ${ }^{(24-26)}$, which culminates in increased release of free fatty acids in the circulation ${ }^{(27)}$. Once the primary means of storage of $\alpha$-tocopherol in the body is the adipose tissue $^{(28)}$, this vitamin can be influenced by increased lipolysis, leading diabetic women to present high concentration of serum tocopherol.

There is evidence that increased oxidative stress may enhance antioxidant enzyme activity in animals, as an adaptive body condition. De Angelis et al found that diabetic rats had an increase of $92 \%$ in catalase activity and of $27 \%$ in glutathione S-transferase in muscles, compared to the control group. As vitamin $\mathrm{E}$ acts as an antioxidant, it is oxidized and transformed into a free radical (tocopherol), thereby, requiring, a regeneration system which allows the recovery of its antioxidant function. Thus, other antioxidants act removing the free radical from the tocopherol molecule, such as ascorbic acid, reduced-glutathione and Coenzyme Q10 ${ }^{(29,30)}$. Giannubilo et al ${ }^{(31)}$ found a significantly higher plasma concentration of coenzyme Q10 in late pregnancy (36-40 weeks) in patients with GDM, when compared to the control group. To explain this difference, the authors suggest that there is a compensatory mechanism in response to oxidative stress associated with hyperglycemia and insulin resistance in patients with GDM.

Considering the studies analyzed and the results obtained, despite the few published articles, we could hypothesize that the increase in $\alpha$-tocopherol in the blood of mothers with GDM is related to the attempt to respond to the disease and minimize damages, in the form of compensatory mechanisms observed both in increased lipolysis in the face of low energy availability and in the increase of antioxidant activity against oxidative stress.

As for the concentration of $\alpha$-tocopherol in colostrum of diabetic mothers, there are few studies on the subject. Despite the scarcity of studies, Lammi-Keefe et $a^{(21)}$ analyzed the amount of vitamin $\mathrm{E}$ in the milk of diabetic mothers in the seventh, 14th, 42th, and 84th days of lactation. In their results, it is observed that the amount of tocopherol in colostrum, which corresponds to sampling in the seventh day, was higher compared to the group of healthy mothers, being a significant difference. In the same group, the vitamin concentration was below the reference value adopted by the authors. This same study also found that the $\alpha$-tocopherol concentrations for diabetic mothers are different from those found in the control group, both in colostrum and in serum; however, in both groups, there was no significant correlation between them, similarly to previous studies, such as those from Azeredo and Trugo ${ }^{(32)}$, Dimenstein et al ${ }^{(33)}$, and Lira et $\mathrm{al}^{(34)}$. This reinforces the hypothesis that there is a different mechanism of tocopherol transfer to the mammary gland in order to meet the needs of the newborn, with no dependence on maternal serum status of this nutrient ${ }^{(32)}$.

In this context, the existence of this independent mechanism is essential, because the maternal body must ensure the transfer of vitamin $\mathrm{E}$ to milk in sufficient quantities for the 
formation of the child's reserves, ensuring protection of the organism against oxygen toxicity and stimulating the development and maintenance of the immune system ${ }^{(4)}$. In addition to its action as an antioxidant, which is extremely important to the newborn, vitamin $\mathrm{E}$ also acts has a modulating function on the post-translation and transcription of genes, antiinflammatory action, and in membrane stability ${ }^{(5,35,36)}$.

Both healthy pregnant women and those with GDM presented adequate nutritional status regarding vitamin $\mathrm{E}$. Nevertheless, the concentration of serum $\alpha$-tocopherol was significantly higher in the diabetic group, being a protective factor against oxidative stress for these women. It is suggested that this increase results from metabolic changes associated with GDM, such as lipolysis.

Regarding study limitations, it is worth mentioning that the test power expresses the probability of detecting a true effect ${ }^{(37)}$. The probability of a researcher committing a type II error, in which he does not discard the null hypothesis when it is false to the population, is designed by beta error $(\beta)^{(38)}$. For sample calculation of this study, we used an $80 \%$ test power and beta error value of $20 \%$. Furthermore, we included some mothers of premature newborns. However, some studies show that gestational age has no influence on the levels of $\alpha$-tocopherol in colostrum ${ }^{(39-41)}$. Finally, we also

\section{References}

1. Einstein FH, Fishman S, Muzumdar RH, Yang XM, Atzmon G, Barzilai N. Accretion of visceral fat and hepatic insulin resistance in pregnant rats. Am J Physiol Endocrinol Metab 2007;294:E451-5.

2. Surapaneni KM. Oxidant-antioxidant status in gestational diabetes patients. $\mathrm{J}$ Clin Diagn Res 2007;1:235-8.

3. Bettencourt JM. Type 2 diabetes mellitus and antioxidant vitamins (vitamin E, vitamin $C$ and $\beta$-carotene) [monograph on the Internet]. Porto: Universidade do Porto; 2010 [cited 2013 Oct 1]. Available from: http://repositorio-aberto. up.pt/bitstream/10216/54615/3/138435_1031TCD31.pdf

3. Debier $\mathrm{C}$, Larondelle $\mathrm{Y}$. Vitamins $\mathrm{A}$ and $\mathrm{E}$ : metabolism, roles and transfer to offspring. Br J Nutr 2005;93:153-74.

5. Traber MG. Vitamin E. In: Bowman BA, Russel RM, editors. Present knowledge in nutrition. $9^{\text {th }}$ ed. Washington DC: ILSI Press; 2006. p. 211-9.

6. Vignini A, Alidori A, Montesi L, Raffaelli F, Nanetti L, Bertoli E et al. Vitamin E, diabetes and related diseases: an update. Mediterr J Nutr Metab 2010;4:3-9.

7. Faul F, Erdfelder E, Lang A-G, BuchnerA. G*Power 3: a flexible statistical power analysis program for the social, behavioral, and biomedical sciences. Behav Res Methods 2007;39:175-91.

8. Subcommittee for a Clinical Application Guide, Committee on Nutritional Status During Pregnancy and Lactation, Food and Nutrition Board, Institute of Medicine, National Academy of Sciences. Nutrition during pregnancy and lactation: an implementation guide. Washington (DC): National Academy Press; 1992.

9. World Health Organization. Neonatal and perinatal mortality: country, regional and global estimates. Geneva: WHO; 2006.

10. Strutz KL, Richardson LJ, Hussey JM. Preconception health trajectories and birth weight in a national prospective cohort. J Adolesc Health 2012:51:629-36. mention the fact that no dietary assessment of pregnant women included in the study was performed and the fact that milk collection was performed only in one period of lactation. Nonetheless, works like this, that verify the association between diseases and the concentration of vitamins in serum and breast milk are relevant to define risk groups for vitamin deficiency.

GDM was not associated with the serum concentration of $\alpha$-tocopherol in colostrum and there seems to be a risk factor for vitamin $\mathrm{E}$ deficiency in newborns whose mothers have this disease. Vitamin concentrations in both groups supply the daily requirement for vitamin $\mathrm{E}$ in infants. In addition, mothers with GDM had higher serum concentrations of $\alpha$-tocopherol, which may be a reflection of physiological and biochemical changes that characterize the disease. Further studies should be conducted to verify the influence of other common diseases in pregnancy on the concentration of $\alpha$-tocopherol and other vitamins in serum and maternal milk.

\section{Acknowledgements}

The authors are thankful to Januário Cicco Maternity School, for the permission to conduct this study, as well as to the mothers who accepted to participate.

11. Ortega RM, López-Sobaler AM, Martínez RM, Andrés P, Quintas ME. Influence of smoking on vitamin $\mathrm{E}$ status during the third trimester of pregnancy and on breast-milk tocopherol concentrations in Spanish women. Am J Clin Nutr 1998;68:662-7.

12. Nierenberg DW, Nann SL. A method for determining concentrations of retinol, tocopherol, and five carotenoids in human plasma and tissue samples. Am J Clin Nutr 1992;56:417-26.

13. Sauberlich HE. Laboratory tests for the assessment of nutritional status. $2^{\text {nd }}$ ed. Boca Raton: CRC Press; 1999.

14. Ribani M, Botolli CB, Jardim IC, Melo LF. Validação de métodos cromatográficos e eletroforéticos. Quim Nova 2004;27:771-80.

15. Ramakrishnan U. Nutrition and low birth weight: from research to practice. Am J Clin Nutr 2004;79:17-21.

16. Ross JS, Harvey PW. Contribuition of breastfeeding to vitamin A nutrition of infants: a simulation model. Bull World Health Organ 2003;81:80-6.

17. Standing Committee on the Scientific Evaluation of Dietary Reference Intakes, Food and Nutrition Board, Institute of Medicine. DRI dietary reference intakes for vitamin C, vitamin E, selenium, and carotenoids. A Report of the Panel on Dietary Antioxidants and Related Compounds. Washington DC: National Academy Press; 2000.

18. Grissa O, Atègbo JM, Yessoufou A, Tabka Z, Miled A, Jerbi M et al. Antioxidant status and circulating lipids are altered in human gestational diabetes and macrosomia. Transl Res 2007;150:164-71.

19. Peuchant E, Brun JL, Rigalleau V, Dubourg L, Thomas MJ, Daniel JY et al. Oxidative and antioxidative status in pregnant women with either gestational or type 1 diabetes. Clin Biochem Rev 2004;37:293-8. 
20. Suhail M, Patil S, Khan S, Siddiqui S. Antioxidant vitamins and lipoperoxidation in non-pregnant, pregnant, and gestational diabetic women: erythrocytes osmotic fragility profiles. J Clin Med Res 2010;2:266-73.

21. Lammi-Keefe CJ, Jonas CR, Ferris AM, Capacchione CM. Vitamin E in plasma and milk of lactating women with insulin-dependent diabetes mellitus. J Pediatr Gastroenterol Nutr 1995;20:305-9.

22. Dey P, Gupta P, Acharya NK, Rao SN, Ray S, Chakrabarty S et al. Antioxidants and lipid peroxidation in gestational diabetes - a preliminary study. Indian $\mathrm{J}$ Physiol Pharmacol 2008;52:149-56.

23. Santra D, Sawhney H, Aggarwal N, Majumdar S, Vasishta K. Lipid peroxidation and vitamin $\mathrm{E}$ status in gestational diabetes mellitus. J Obstet Gynaecol 2003;29:300-4.

24. Andrade OV, Ihara FO, Troster EJ. Metabolic acidosis in childhood: why, when and how to treat. J Pediatr (Rio J) 2007;83 (Suppl 2):S11-21.

25. Barone B, Rodacki M, Cenci MC, Zajdenverg L, Milech A, Oliveira JE. Cetoacidose diabética em adultos - atualização de uma complicação antiga. Arq Bras Endocrinol Metab 2007;51:1434-47.

26. Rodacki M, Zajdenverg L, Lima GA, Nunes RC, Milech A, Oliveira JE. Relato de caso: diabetes flatbush - da cetoacidose ao tratamento não-farmacológico. Arq Bras Endocrinol Metab 2007;51:131-5.

27. Fulop T, Tessier D, Carpentier A. The metabolic syndrome. Pathol Biol (Paris) 2006;54:375-86.

28. Herrera E, Barbas C. Vitamin E: action, metabolism and perspectives. J Physiol Biochem 2001;57:43-56.

29. De Angelis KL, Cestari IA, Barp J, Dall'ago P, Fernandes TG, de Bittencourt $\mathrm{PI}$ et al. Oxidative stress in the latissimus dorsi muscle of diabetic rats. Braz J Med Biol Res 2000;33:1363-8.

30. Catania AS, Barros CR, Ferreira SR. Vitamins and minerals with antioxidant properties and cardiometabolic risk: controversies and perspectives. Arq Bras Endocrinol Metab 2009;53:550-9.
31. Giannubilo SR, Tiano L, Cecchi S, Principi F, Tranquilli AL, Littarru GP. Plasma coenzyme $Q_{10}$ is increased during gestational diabetes. Diabetes Res Clin Pract 2011;94:230-5.

32. DeAzeredo VB, Trugo NM. Retinol, carotenoids, and tocopherols in the milk of lactating adolescents and relationships with plasma concentrations. Nutrition 2008;24:133-9.

33. Dimenstein R, Pires JF, Garcia LR, Lira LQ. Levels of alpha-tocopherol in maternal serum and colostrum of adolescents and adults. Rev Bras Ginecol Obstetr 2010;32:267-72.

34. Lira LQ, Lima MS, de Medeiros JM, da Silva IF, Dimenstein R. Correlation of vitamin A nutritional status on alpha-tocopherol in the colostrum of lactating women. Matern Child Nutr 2013;9:31-40.

35. Zingg JM, Azzi A. Non-antioxidant activities of vitamin E. Curr Med Chem 2004;11:1113-33.

36. Rizzo MR, Abbatecola AM, Barbieri M, Vietri MT, Cioffi M, Grella R et al Evidence for anti-inflammatory effects of combined administration of vitamin $E$ and $\mathrm{C}$ in older persons with impaired fasting glucose: impact on insulin action. J Am Coll Nutr 2008;27:505-11.

37. Normando D, Almeida MA, Quintão CC. Análise do emprego do cálculo amostral e do erro do método em pesquisas científicas publicadas na literatura ortodôntica nacional e internacional. Dental Press J Orthod 2011;16:e1-9.

38. Carneiro AV. Cálculo da dimensão da amostra em estudos clínicos: princípios metodológicos básicos. Rev Port Cardiol 2003;22:1513-21.

39. Grilo EC, Lira LQ, Dimenstein R, Ribeiro KD. Influência da prematuridade e do peso ao nascer sobre a concentração de $\alpha$-tocoferol no leite colostro. Rev Paul Pediatr 2013;31:473-9.

40. Haug M, Laubach C, Burke M, Harzer G. Vitamin E in human milk from mothers of preterm and term infants. J Pediatr Gastr Nutr 1987;6:605-9.

41. Zheng MC, Zhang GF, Zhou LS, Guo XG, Quan YF. Alpha-tocopherol concentrations in human milk from mothers of preterm and full-term infants in China. Biomed Environ Sci 1993;6:259-64. 